\title{
Mednarodno sodelovanje $v$ davčnih zadevah v Evropski uniji
}

UDK: 336.2(495.12)

\author{
Aleksandra Heinzer \\ aleksandra.heinzer@siol.net
}

IZVLEČEK

V prispevku obravnavamo pomen mednarodnega sodelovanja $\mathbf{v}$ davčnih zadevah kot eno izmed pomembnih novosti, ki jo vzporedno s polnopravnim članstvom Slovenije v EU prinaša Zakon o davčnem postopku. Ključni faktor na tem področju je vloga evropskega prava, zato poudarjamo njegov vpliv na slovensko upravo. Pojasnjujemo, kakšna je dejanska vloga upravne pomoči med članicami, opredeljujemo njen pojem in datiramo razvoj pravne podlage za njeno izvajanje.

Nadalje podrobno analiziramo celotno poglavje Zakona o davčnem postopku, ki zajema to tematiko, pri čemer se osredotočimo predvsem na odnos med pristojnimi organi držav članic. V zvezi z uveljavitvijo zakona izpostavljamo neskladje z Ustavo Republike Slovenije in opozarjamo na kolizijo, ki prihaja med njim in direktivo, ki jo zakon inkorporira.

Končno ugotavljamo, da tovrstno povezovanje med državami glede izmenjave izkušenj prinaša pozitivne posledice tudi za Slovenijo.

Ključne besede: mednarodno sodelovanje, upravna pomoč, davčni postopek, Evropska unija, izterjava davščin

\section{Uvod}

Vzpostavitev enotnega tržišča Evropske unije (v nadaljevanju EU) sili države članice k harmonizaciji davčnih sistemov. Za EU je ta cilj velik izziv, saj so davčni sistemi znotraj posameznih držav še vedno precej zapleteni. K njihovi zapletenosti pripomorejo različni zgodovinski razlogi in zasledovanje ciljev družbene pravičnosti, poleg tega pa so davščine tudi instrument politike. Dober davčni sistem se razvija na podlagi načel ekonomske učinkovitosti, pravičnosti, administrativne enostavnosti in transparentnosti, fleksibilnosti ter demokratičnosti v sprejemanju odločitev o davščinah. Pomembno vlogo pri tem razvoju ima davčna administracija, ki vpliva na efektivno davčno obremenitev. Obstaja namreč razlika med dejansko pobranimi in potencialno možnimi davščinami, zato je zelo pomembno, kako se ti dejansko pobirajo. V vrsti mehanizmov za 


\section{Aleksandra Heinzer \\ Mednarodno sodelovanje \\ v davčnih zadevah v Evropski uniji}

preprečevanje in odkrivanje ter odpravljanje številnih dejanj na področju davčne utaje sta medsebojno administrativno sodelovanje in vzajemna pomoč med državami članicami izrednega pomena, saj sledita skupnemu cilju, to je finančnemu interesu. Sodelovanje tako obsega medsebojno pomoč na upravnem ali kazenskem področju. Narava posameznega primera pogojuje odločitev, za katero pomoč bo država članica $\vee$ danem primeru zaprosila, pri čemer sta večkrat obe področji med seboj močno povezani. $\vee$ prispevku želimo izpostaviti predvsem upravno sodelovanje med državami članicami v davčnih zadevah, pri čemer kazenskega področja podrobneje ne analiziramo'. $V$ tej povezavi uvodoma povzemamo definicijo davka po Jerovšek ${ }^{2}$ :

"Davek je obveznost posameznika ali pravne osebe prispevati od svojih doseženih dohodkov ali premoženja in pravic za skupne družbene potrebe $v$ višini in na način, ki ga določi zakon".

\section{Vpliv evropskega prava na slovensko upravo}

Upoštevajoč načela avtonomnosti, primarnosti in neodvisnosti prava EU so s podpisom pogodbe o pristopu k EU za Republiko Slovenijo (v nadaljevanju RS) postali zavezujoči tako njeni primarni kot sekundarni pravni viri evropskega prava $^{\mathbf{3}}$. To predstavlja težko preizkušnjo tudi za slovensko upravo (in z njo davčno ter carinsko upravo), saj je po uspešni vključitivi RS v EU od 1. 5. 2005 ključni akter na področju izvrševanja evropskega prava, pri čemer je bilo treba uvesti vrsto pomembnih sprememb ${ }^{\mathbf{4}}$.

$\checkmark$ okviru načela zakonitosti so upravni organi RS dolžni delovati v skladu z ustavo in zakoni, od maja 2004 pa v skladu z veljavno evropsko zakonodajo, ki $\checkmark$ primeru konflikta zaradi načela neposredne uporabe nacionalno zakonodajo nadredi brez predhodne presoje skladnosti nižjih predpisov z višjimi.

V okviru obveznih aktov sekundarne evropske zakonodaje poznamo:

- Uredbe, ki jih v nacionalni pravni red ni treba, oziroma je celo prepovedano vnašati ${ }^{5}$;

- Direktive, ki so podlaga zakonodajalcu v posamezni državi članici, da uredi določeno področje, pri čemer je pomembno navesti poudarek znotraj sodnega primera. "Država članica, ki ni izvedla ukrepov, ki so

1 Več o tej povezavi glej v Vervaele in Klip (2001, str. 7-47).

2 Jerovšek, T. (2004, str. 2).

3 Več o tem delitvi glej v Grilc in Ilešič (2004, str. 81-91).

4 Glej Bugarič (2004, str. 101-105).

5 Glej Grilc in Ilešič (2004, str. 110-111). 


\section{Aleksandra Heinzer \\ Mednarodno sodelovanje v davčnih zadevah v Evropski uniji}

ji bili z direktivo naloženi, se v razmerju do posameznih subjektov ne more sklicevati na opustitev izvršitve svoje obveznosti (Grilc in Ilešič, 2004, str. 115);

- Odločbe - individualni akti, ki veljajo neposredno za tistega, na katerega so naslovljeni'.

Omenjeno se predvsem nanaša na delovanje uprave, vprašanje glede strukture in organizacije državne uprave pa ni del evropskega prava. Tovrstno ureditev ni moč najti niti v primarni niti v sekundarni zakonodaji, pač pa je to domena posamezne države članice. Nacionalne državne uprave se pogosto označuje kot »nevidni« steber oziroma "četrti« steber EU, saj državna uprava ni izrecno urejena $\vee$ ustanovnih pogodbah Evropske skupnosti oziroma EU (Bugarič, 2004, str. 101).

Za uspešno uresničevanje vedno novih ciljev, ki si jih države članice zastavljajo, bo potrebna tudi ustrezna in učinkovita »infrastruktura «, s katero bo te cilje mogoče doseči.

\section{Upravna pomoč v EU}

Upravno pravo je še relativno mlado področje, saj se je $\vee$ Evropi razvilo šele $\vee$ devetnajstem stoletju ${ }^{7}$. Odnosi med subjekti znotraj zasebne sfere so tako nedvomno trdnejši, kot so odnosi med upravami posameznih evropskih držav. Da je medsebojno sodelovanje izrednega pomena za vse članice, dokazuje tudi izraz skupne politike v Pogodbi o Ustavi za Evropo ${ }^{8}$.

\subsection{Razvoj pravne podlage za medsebojno upravno pomoč}

Področje upravne pomoči, katere težišče je bilo od nekdaj predvsem pobiranje davščin, med posameznimi državami $\vee$ Evropi $\vee$ primerjavi s sodelovanjem med državami na področju civilnega in kazenskega prava nima posebne

6 Grilc in Ilešič, 2004, str. 112, navajata celo sodni primer, ko je sodišče odgovorilo pritrdilno na vprašanje, ali naj se na odločbo sklicujejo tudi posamezniki, na katere se odločba ne nanaša.

7 Schwarze, 1992, str. 77 navaja: Od razvoja upravnega prava v devetnajstem stoletju je število razmerji med državljani in upravami posameznih držav strmo narašča in je celo doseglo število razmerji med subjekti znotraj civilnega prava.

8 "Učinkovito nacionalno izvajanje prava Unije s strani držav članic, kar je bistveno za pravilno delovanje Unije, se šteje za zadevo skupnega interesa." (prvi odstavek 285. člena Pogodbe o Ustavi za Evropo) 


\section{Aleksandra Heinzer \\ Mednarodno sodelovanje \\ v davčnih zadevah v Evropski uniji}

tradicije. Po drugi svetovni vojni je bilo sprejetih nekaj mednarodnih pogodb med državami, predvsem na področju preprečevanja dvojnega obdavčevanja in carinskih zadev. $\vee$ sedemdesetih letih prejšnjega stoletja sta bili sprejeti dve konvenciji Sveta Evrope ${ }^{9}$, ki pa se v praksi nista popolnoma izvajali.

Možnost vzpostavitve medsebojne vzajemne upravne pomoči med vsemi državami članicami konkretneje podaja Amsterdamska pogodba o ustanovitvi Evropske skupnosti (v nadaljevanju ES):

"Svet $v$ skladu s postopkom iz člena 67 sprejme ukrepe za zagotovitev sodelovanja med ustreznimi upravnimi službami držav članic na področju iz tega naslova ter med temi službami in Komisijo. " (Pogodba o ustanovitvi ES, 66.člen)

Poleg navedenega člena je pomemben tudi 135. člen omenjene pogodbe, ki omogoča okrepitev carinskega sodelovanja med državami članicami ter med njimi in Komisijo.

Nadalje je bilo sprejetih več predpisov, vendar naj omenimo le nekatere med njimi. Direktiva 77/779/EGS je temeljni dokument, ki ureja sodelovanje med pristojnimi organi držav članic EU. Ta direktiva je bila sprva namenjena urejanju sodelovanja davčnih oblasti na področju neposrednih davkov, z direktivo 79/1070/EGS pa se njena določila razširijo še na področje posrednih davkov.

27. januarja 1992 je Svet EU sprejel uredbo EGS 218/92, ki je prav tako namenjena administrativnemu sodelovanju davčnih organov držav članic EU. Sprejetje te direktive je predvsem posledica ukinitve fizične carinske kontrole znotraj EU, ureja pa načine in postopke $v$ zvezi z elektronsko in tudi drugo izmenjavo podatkov ter $v$ intrakomunitarnih transakcijah, ki se dogajajo med zavezanci za DDV iz različnih članic EU. Kasnejša uredba 1798/2003/ES povezuje direktivo 77/779/EGS in uredbo EGS 218/92 in vnaša nekatere spremembe, ki bi omogočale učinkovitejše upravno sodelovanje. Uredba tako predvideva tesnejše stike med davčnimi službami, večji poudarek pa namenja spontani in avtomatični izmenjavi podatkov.

\subsection{Opredelitev upravne pomoči}

Za opredelitev upravne pomoči so potrebni trije ključni parametri: pristojnost, načini in namen ${ }^{\mathbf{1 0}}$.

9 Evropska konvencija o uradnem vračanju dokumentov, ki se nanašajo na administrativne zadeve v tujini, Strasbourg, 24.11.1977 in Evropska konvencija o pridobivanju informacij in dokazov v administrativnih zadevah v tujini, Strasbourg, 15.3.1978.

10 Klip in Vervaele, 2001, str. 12-28 


\section{Aleksandra Heinzer \\ Mednarodno sodelovanje v davčnih zadevah v Evropski uniji}

\section{Pristojnost organov $v$ procesu medsebojne upravne pomoči}

Pristojnost organov, ki nudijo upravno pomoč, je $v$ domeni posamezne države članice in je povezana s samo upravno strukturo znotraj nje. V Sloveniji te pristojnosti $\vee$ davčnih zadevah podeljuje Zakon o davčnem postopku" ( $v$ nadaljevanju ZDavP-1). Za upravno pomoč $v$ davčnih zadevah so tako $v$ Sloveniji pooblaščeni Ministrstvo za kmetijstvo, gozdarstvo in prehrano, Ministrstvo za finance ter carinska in davčna uprava. Potrebno je poudariti, da $v$ tem kontekstu upravna pomoč ne poteka le med posameznimi državami članicami, oziroma med njihovimi pristojnimi institucijami, pač pa tudi med državami članicami in Evropsko komisijo kot pristojno institucijo EU. V prvem primeru govorimo o horizontalni, v drugem pa o vertikalni vzajemni upravni pomoči.

\section{Načini izvajanja medsebojne upravne pomoči}

Ločimo naslednje načine izvajanja upravne pomoči:

- izmenjava informacij med pristojnimi organi, ki poteka avtomatično, spontano ali na podlagi zaprosila;

- učinkovit nadzor nad pretokom oseb in blaga (meje med državami članicami so odpravljene, s tem pa je fizični nadzor na področju intrakomunitarnega pretoka oseb in blaga skorajda nemogoč);

- uveljavljen upravni nadzor na nacionalni in mednarodni ravni;

- ustanovitev oddelka za mednarodno izmenjavo podatkov (CLO ${ }^{\mathbf{2 2}}$ ) medsebojne elektronske povezave in

- ustanovitev skupnega komunikacijskega omrežja med pristojnimi organi.

\section{Namen upravne pomoči}

Nudenje medsebojne upravne pomoči omogoča posameznim organom, da pridobijo informacije, ki so odločilne pri sprejemanju določenih ukrepov zoper zavezance.

11 Zakon o davčnem postopku /ZDavP-1/ (25/05 - UPB)

12 Central Liaison Office 


\section{Aleksandra Heinzer \\ Mednarodno sodelovanje \\ v davčnih zadevah v Evropski uniji}

\section{Davčni postopek v Sloveniji}

\subsection{Novi davčni postopek}

Mednarodno sodelovanje $v$ davčnih zadevah se $v$ RS izvaja $v$ okviru davčnega postopka kot posebnega upravnega postopka. Pravila EU sicer zapovedujejo načine komuniciranja, sodelovanja, načine prenosov podatkov in informacij med pristojnimi organi, vendar pa organ $v$ odnosu do zavezanca ravna po pravilih davčnega postopka RS, katerega skelet je ZdavP - 1. Državni zbor ga je sprejel 23. aprila 2004, uporabljati pa se je začel 1. januarja 2005, razen določb o o zavarovanju izpolnitve in plačila davčne obveznosti, o razkritju podatkov upravičeni osebi, o davčni izvršbi in tudi celotno poglavje o mednarodnem sodelovanju $\vee$ davčnih zadevah. Te določbe se uporabljajo že od 1. maja $2004^{\mathbf{1 3}}$, 35. člen pa se uporablja od 21.05.2004.

Zakon je bil objavljen v Uradnem listu RS z dne 20. 5. 2004, začel pa je veljati 21. 5. 2004. Nekatere njegove določbe so se začele uporabljati 1.05.2005, kar pomeni kršenje 154. člena ustave, ki določa, da morajo biti vsi državni predpisi objavljeni $v$ državnem uradnem listu, preden začno veljati (prepoved retroaktivne veljave). Poleg tega je obveščenost zavezancev eden temeljnih pogojev, da se vzpostavi čim bolj učinkovito pobiranje davščin. Država naj že v samem izhodišču obravnava zavezance kot zveste državljane, ki prostovoljno izpolnjujejo davčne obveznosti in ne kot potencialne utajevalce, ki jim ni mar za ažurnost in pravočasno osveščenost.

Zakon o davčnem postopku ${ }^{14}$, ki je bil prvič objavljen leta 1996 ( $v$ nadaljevanju ZDavP), je doživel kar sedem sprememb, Ustavno sodišče pa je kar z devetimi odločbami odločilo o njegovi neustavnosti. K sprejetju novega zakona je predvsem botrovala vključitev Slovenije $v$ EU, težnja po koordinaciji davkov pa zahteva tudi odpravo številnih administrativnih ovir. V ZDavP-1 se kot nov davčni organ pojavi tudi Carinska uprava, ki ji novela Zakona o carinski službi ${ }^{\mathbf{1 5}}$ bistveno spreminja obseg nalog. Stvarno pristojnost dodeljuje tudi drugim organom, na primer javnemu zavodu RTV. Pomembna novost pa je obravnava inšpekcije.

13 35. člen tega zakona pa se je začel uporabljati z dnem uveljavitve tega zakona, torej 21. 5. 2004. 14 Zakon o davčnem postopku /ZDavP/ (Ur.I. RS, št. 18/1996, 78/1996 Skl.US: U-I-376/96, 87/1997, 35/1998 OdI.US: U-I-376/96-9, 82/1998, 91/1998, 1/1999, 108/1999, 37/2001 OdI.US: U-I-18/98-20, 97/2001, 31/2003 Odl.US: U-I-72/00-15, 33/2003 Skl.US: U-I-108/99-14, 105/2003 OdI.US: U-I-252/0012, 16/2004 Odl.US: U-I-233/01-14, 42/2004 Odl.US: U-I-329/02-7, 54/2004, 109/2004 Odl.US: U-I356/02-14).

15 Zakon o carinski službi /ZCS-1/(Ur.l. RS, št. 56/1999, 52/2002, 110/2002, 57/2004). 


\section{Aleksandra Heinzer \\ Mednarodno sodelovanje v davčnih zadevah v Evropski uniji}

ZDavP-1 je glede na ZDavP precej obsežnejši, saj vsebuje več kot 400 členov. Zakon $\vee$ prvem delu zajema postopek na splošno (1. - 250. člen), v drugem delu pa postopke glede posameznih davkov.

Poglavitna novost je uvedba predpisov EU. Novi ZDavP-1 tako povzema nekatere direktive, ki pomembno prispevajo $k$ učinkovitosti delovanja uprave na tem področju, saj izogibanje davkom in davčna evazija že dolgo presegata dejanske meje med državami. Poglavje o mednarodnem sodelovanju je tako eno ključnih novosti novega zakona. Pri tem gre le za sodelovanje med članicami $\mathrm{EU}^{\mathbf{1 6}}$.

Institut mednarodnega sodelovanja $\vee$ ZDavP -1 , ki se nahaja $\vee$ četrtem delu zakona (199.-249.čl.), obsega dve področji:

- pobiranje davkov in

- izmenjavo podatkov.

$\checkmark$ ta del zakona so bile vključene naslednje direktive institucij EU:

- Direktiva Sveta 76/308/EGS z dne 15. marca 1976 o vzajemni pomoči pri izterjavi terjatev iz poslovanja, ki je del sistema financiranja Evropskega kmetijskega usmerjevalnega in jamstvenega sklada, ter iz prelevmanov in carin";

- Direktiva Komisije 2002/94/ES z dne 9. decembra 2002 o določitvi podrobnih pravil za izvajanje nekaterih določb Direktive Sveta 76/308/EGS o vzajemni pomoči pri izterjavi terjatev v zvezi z prelevmani, davki in drugimi ukrepi ${ }^{\mathbf{1}}$;

- Direktiva Sveta 77/799/EGS z dne 19. decembra 1977 o medsebojni pomoči pristojnih organov držav članic na področju neposredne obdavčitve ${ }^{19}$;

16 Sprva je bilo v EU samo šest držav: Belgija, Nemčija, Francija, Italija, Luksemburg in Nizozemska. Danska, Irska in Združeno kraljestvo so se pridružili leta 1973, Grčija 1981, Španija in Portugalska 1986 ter Avstrija, Finska in Švedska leta 1995. Leta 2004 se je Evropski uniji v največji širitvi doslej pridružilo 10 novih držav: Madžarska, Poljska, Litva, Latvija, Malta, Ciper, Slovaška, Češka republika, Estonija in Slovenija.

17 31976L0308 Council Directive 76/308/EEC of 15 March 1976 on mutual assistance for the recovery of claims resulting from operations forming part of the system of financing the European Agricultural Guidance and Guarantee Fund, and of the agricultural levies and customs duties.

18 32002L0094 Commission Directive 2002/94/EC of 9 December 2002 laying down detailed rules for implementing certain provisions of Council Directive 76/308/EEC on mutual assistance for the recovery of claims relating to certain levies, duties, taxes and other measures. 19 31977L0799 Council Directive 77/799/EEC of 19 December 1977 concerning mutual assistance by the competent authorities of the Member States in the field of direct taxation. 
Aleksandra Heinzer

Mednarodno sodelovanje

v davčnih zadevah v Evropski uniji

- Direktiva Sveta 2003/48/ES z dne 3. junija 2003 o obdavčitvi dohodka od prihrankov v obliki plačil obresti ${ }^{\mathbf{2 0}}$;

- Direktiva Sveta 2003/49 z dne 3. junija 2003 o skupnem sistemu obdavčevanja v zvezi s plačili obresti in plačili uporabe premoženjskih pravic, ki velja za povezane družbe različnih držav članic ${ }^{\mathbf{2 1}}$.

\subsection{Medsebojna upravna pomoč med državami članicami EU pri izterjavi davščin}

Uspešna izterjava, pregon in nenazadnje tudi kaznovanje davčnih utajevalcev je pomembno področje dela davčnih in drugih upravnih organov. Država in s tem njeni državljani so s takšnimi in podobnimi goljufijami oškodovani, zato so zainteresirani, da se davki korektno plačujejo in uspešno pobirajo, sicer je potrebno pridobiti nadomestne vire za pokrivanje izgube, ki pri tem nastane. Nadomestni viri so lahko predvsem še višji davki, ki jih spet plačujejo pošteni zavezanci. Medsebojna pomoč $\vee$ odkrivanju goljufij je torej $\vee$ interesu vseh držav članic, kar opravičuje vzajemnost te pomoči.

ZDavp-1 določa, kdo v postopku medsebojne upravne pomoči nastopa:

- organ prosilec, to je pristojni organ države članice, ki pošlje prošnjo za pomoč v zvezi s terjatvami;

- zaprošeni organ, to je pristojni organ države članice, kateremu se pošlje prošnja za pomoč.

Upravna pomoč se lahko nanaša na:

- pridobitev podatkov, pomembnih za odmero davčne obveznosti davčnega zavezanca $v$ drugi državi članici EU;

- vročitev dokumentov, povezanih z davčno obveznostjo davčnega zavezanca v drugi državi članici EU;

- izterjavo davčnih obveznosti davčnega zavezanca $\vee$ drugi državi članici EU;

- zavarovanje izpolnitve davčnih obveznosti davčnega zavezanca v drugi državi članici EU.

20 32003L0048 Council Directive 2003/48/EC of 3 June 2003 on taxation of savings income in the form of interest payments.

21 32003L0093 Council Directive 2003/93/EC of 7 October 2003 amending Council Directive $77 / 799 / E E C$ concerning mutual assistance by the competent authorities of the Member States in the field of direct and indirect taxation. 


\section{Aleksandra Heinzer \\ Mednarodno sodelovanje v davčnih zadevah v Evropski uniji}

Pristojni organ prejeta zaprosila za pomoč pošlje $v$ izvršitev davčnemu organu, ki je v skladu z ZdavP - 1 pristojen za izvršbo ${ }^{22}$. Davčni organ v postopku izvršbe upošteva tudi obresti, upravne kazni in globe ter stroške, povezane z vsemi naštetimi dajatvami, razen denarnih kazni za kazniva dejanja.

\section{Stroški}

Zaprošenemu organu pripadajo vsi stroški, ki jih ima v zvezi s postopkom izvršbe, krije pa jih dolžnik. Za stroške, ki nastanejo v zvezi s preostalim obsegom mednarodne upravne pomoči pri izterjavi davščin, se države članice odrekajo vsem vzajemnim terjatvam drugih držav članic, razen $\vee$ primeih, ko je zaprosilo za medsebojno pomoč neutemeljeno bodisi zaradi same vrste terjatve bodisi zaradi veljavnosti dokumenta.

\section{Zaprosilo za medsebojno pomoč}

Zaprosilo za medsebojno pomoč organ prosilec lahko predloži, če znesek davščine ni nižji od tolarske protivrednosti 1.500 evrov (trenutno približno 375.000 tolarjev).

Vrste zaprosil so naslednje:

- zaprosilo za pridobitev podatkov,

- zaprosilo za vročitev,

- zaprosilo za izterjavo,

- zaprosilo za zavarovanje izpolnitve davčne obveznosti.

Zakon $\vee$ 220. členu določa pogoje in vsebino zaprosila za izterjavo, pri čemer pride do kolizije med samim zakonom in direktivo, ki jo le-ta vključuje. Direktiva (76/308/EGS) v drugem odstavku 7. člena določa, da organ prosilec ne sme predložiti prošnje za izterjavo, če je $v$ državi članici, $v$ kateri ima sedež, že začel ustrezen postopek za izterjavo, ki mu je na voljo na podlagi izvršilnega naslova, in na podlagi tega postopka ni dobil celotnega povračila. ZDavP - 1 pa $\checkmark$ drugi alineji drugega odstavka 220. člena določa ravno nasprotno, torej da $v$ tem primeru organ države zaprosilke lahko predloži zaprosilo za izterjavo. Postavi se vprašanje, kako bo davčni organ $v$ takem primeru dejansko ravnal. Kljub dejstvu, da je nacionalna zakonodaja $v$ neskladju z zakonodajo EU, je davčni organ zavezan ravnati $v$ skladu z evropskim pravom, sicer se šteje, da je ravnal

22 Na podlagi 4. člena ZDavP-1 so pristojni Davčna uprava, Carinska uprava in Ministrstvo za finance. 


\section{Aleksandra Heinzer \\ Mednarodno sodelovanje \\ v davčnih zadevah v Evropski uniji}

$\checkmark$ nasprotju tako z evropskim kot z nacionalnim pravom, torej da je ravnal nezakonito. Pri koliziji aktov EU in aktov notranjih organov imajo primat predpisi EU, kar je posledica primarnosti oziroma prevlade prava $\mathrm{EU}^{\mathbf{2 3}}$.

Obrazce - obliko zaprosil predpiše minister za finance s pravilnikom, ki je bil sprejet konec leta $2004^{\mathbf{2 4}}$. Zakon sam določa, da morajo biti zaprosila in spremljajoči dokumenti prevedeni $v$ slovenski jezik, razen če gre za enostavno zadevo in organ oceni, da mu prevod ni potreben. $V$ nasprotnem primeru zaprošeni organ organa prosilca pozove, naj vlogo dopolni. Če je ta ne dopolni, zaprošeni organ naredi na zaprosilo uradni zaznamek in obvesti organa prosilca, da zaprosila ne bo obravnaval| ${ }^{25}$.

Vse medsebojne informacije, ki morajo biti $v$ pisni obliki, se pošiljajo $\vee$ elektronski obliki, razen zaprosil za vročitev in izterjavo, ki morata biti pisna (lahko tudi v elektronski obliki, po dogovoru med organoma). Direktiva komisije 2002/94/ES v drugem členu loči dva načina elektronskega prenosa:

- $\quad$ renos z elektronskimi sredstvi, to je prenos z elektronsko opremo za obdelavo podatkov ter uporabo kabelskega omrežja, radijskega sistema prenosa, optične tehnologije ali drugih elektromagnetnih sredstev;

- omrežje CCN/CSI, to je skupno komunikacijsko omrežje (CCN) in sistem skupnega vmesnika (CSI), ki ju je razvila EU.

Vse informacije, ki potekajo med organoma, veljajo za davčno tajnost ${ }^{\mathbf{2 6}}$. Pravico do vpogleda $v$ dokumente in podatke imajo:

- osebe, navedene na zaprosilu;

- organi, ki so pristojni za izvršbo;

- sodni organi, ki obravnavajo zadeve v zvezi z izvršbo.

Organ mora $\vee 7$ dneh od dneva prejema zaprosila prejem pisno potrditi. Organa prosilca lahko prosi za dodatne podatke, če pa jih ta ne posreduje, postopek nadaljuje, če je to mogoče. Če to ni mogoče, ga obvesti, da zaprosila ne bo izpolnil.

23 Po Grilc in llešič, 2004, str. 102.

24 Pravilnik o obrazcih za zahtevke za uveljavitev ugodnosti iz mednarodnih pogodb o izogibanju dvojnega obdavčevanja (Ur.I. RS, št. 138/2004).

$25 \mathrm{~V}$ primeru, ko organ oceni, da prevod ni potreben, to ne pomeni posega $\mathrm{v}$ pravico stranke glede uporabe jezika.

26 Davčni organ mora varovati vsa dejstva in okoliščine, skupaj s podatki, ki so poslovna skrivnost in podatki, ki so zaupni po drugih predpisih. Dolžnost varovanja podatkov pomeni, da morajo podatke varovati vsi davčni organi, izvedenci, zapisnikarji in vse druge osebe, ki bi kakorkoli prišle $v$ stik $z$ davčnimi podatki, vsak tovrsten dokument pa mora biti označen kot davčna tajnost. 


\section{Aleksandra Heinzer \\ Mednarodno sodelovanje v davčnih zadevah v Evropski uniji}

Kadar organ ne more izpolniti zaprosila $v$ razumnem roku, o tem obvesti organa prosilca. $\vee$ vsakem primeru pa organ vsakih 6 mesecev obvešča organa prosilca o trenutnem stanju, ta pa se $\vee 2$ mesecih odloči, ali naj zaprošeni organ postopek nadaljuje ali ne.

\subsection{Medsebojna pomoč pri izmenjavi podatkov med članicami EU}

Države lahko uvedejo davčne zahteve proti subjektom, ki so vezani na teritorialno suverenost države prek naveznih okoliščin, ki so lahko osebne (glede na državljanstvo in rezidentstvo) ali realne (glede na vir dohodka). $V$ okviru teh okoliščin ločimo:

- omejeno davčno zavezo, ko ima država pravico, da obdavči zavezance samo glede prihodka, ki izhaja iz izvora države rezidentstva;

- neomejeno davčno zavezo, ko država razširja svojo nacionalno suverenost preko svojih teritorialnih meja (Kovač M., 2004, str. 120).

$\checkmark$ primeru neomejene davčne zaveze ima torej država pravico do obdavčenja svetovnega dohodka, ki ga zavezanec prejme.

Drugo in tretje poglavje četrtega dela ZDavP - 1 določata pogoje in način izmenjave podatkov med članicami EU za posamezne vrste davščin: posredne davke, neposredne davke, trošarine, davke na zavarovalne premije ${ }^{\mathbf{2 7}}$. Pomoč obsega tri vrste izmenjave:

- Izmenjava na podlagi zahteve pristojnega organa (izvaja se zgolj na podlagi zaprosila);

- Avtomatična izmenjava podatkov (sistematično pošiljanje že v naprej določenih podatkov na podlagi dogovora, pri tem organu pošiljatelju ni potrebno presojati ali bodo podatki prejemniku koristili);

- Spontana izmenjava podatkov (nesistematično pošiljanje podatkov, za katere se domneva, da bi prejemniku koristile).

Pomembno vlogo pri izmenjavi informacij glede davka na dodano vrednost ( $v$ nadaljevanju DDV) kot posrednega davka, ima elektronska baza podatkov "VAT Information Exchange System" (v nadaljevanju VIES). VIES, ki deluje že od leta 1992, omogoča davčnim organom vseh članic enostavnejšo izmenjavo

27 Kranjec, 2003, str. 57 navaja: "Tradicionalna definicija pravi, da so posredni davki tisti, ki povišujejo cene (se prevaljujejo naprej), neposredni pa tisti, ki zmanjšujejo dohodek zavezanca (se prevaljujejo nazaj). Taki so carine, trošarine, DDV, davki na promet nepremičnini ipd. Dohodnina, davki od dobička in premoženjski davki pa so posredni davki.» 


\section{Aleksandra Heinzer \\ Mednarodno sodelovanje \\ v davčnih zadevah v Evropski uniji}

podatkov glede plačevanja DDV-ja, zmanjša pa se tudi možnost izogibanja plačilu davka, ki ga podjetja plačujejo po načelu destinacije. Baza vsebuje podatke o nabavah in prodajah za obdobje petih let, skupno vrednost nabav med članicami EU ter med posameznimi podjetji, organi pa so dolžni ravnati $\vee$ skladu z načelom varovanja podatkov. Brezplačen dostop do podatkov je Evropska komisija omogočila tudi podjetjem z objavo VIES-a na svoji spletni strani. Od 14.06.2002 dalje tako lahko posamezna podjetja iz različnih držav pridobijo podatke o identifikacijskih šrevilkah davčnih zavezancev.

\subsection{Izvajanje mednarodnih pogodb o izogibanju dvoj- nega obdavčevanja}

Vsaka izmed držav članic je vsekakor zainteresirana za kakršnekoli tuje investicije, saj le-te pospešujejo rast narodnega gospodarstva. Dvojno obdavčevanje je za investicije resna ovira, zato so vse mednarodne pogodbe sprejete z namenom odpraviti dvojno obdavčevanje izredno pomembne. Za lažje razumevanje najprej pojasnimo pojem dvojnega obdavčevanja:

"O primeru dvojnega obdavčenja govorimo takrat, kadar dve davčni oblasti na istem nivoju obdavčita $v$ istem časovnem razdobju, $z$ istim ali podobnim davkom isti davčni subjekt, kar ima za posledico, da je davčni subjekt ali objekt obdavčen težje, kot če bi ga obdavčila samo ena davčna oblast« (Hanžeković v Kovač, 2004, str. 120).

Kot primer lahko navedemo obdavčevanje pokojnin. Lahko se zgodi, da zavezanec plačuje prispevke za pokojninsko in invalidsko varnost $v$ državi, kjer so ti prispevki obdavčeni, nato pa pokojnino prejema $v$ državo, kjer je tudi ta obdavčena. Problem glede dvojnega obdavčevanja je predvsem rešen s konvencijo OECD (Model OECD), ki ima močan vpliv tudi na bilateralno reševanje dvojnega obdavčevanja ${ }^{\mathbf{2 8}}$.

Četrto poglavje četrtega dela ZDavP - 1 določa postopek skupnega dogovora $v$ skladu $z$ mednarodno pogodbo o izogibanju dvojnega obdavčevanja na zahtevo davčnega zavezanca ali na pobudo pristojnega organa druge države. Določa tudi pravila uveljavljanja ugodnosti, kot je znižanje, oprostitev ali vračilo davčnega odtegljaja, uveljavljanje ugodnosti $\vee$ davčnem obračunu ter $\vee$ napovedi.

28 Več o tem Kovač, 2004, str. 139-180. 


\section{Aleksandra Heinzer \\ Mednarodno sodelovanje v davčnih zadevah v Evropski uniji}

\section{Sklepne misli}

Dejstvo je, da EU kot integracija temelji na gospodarskih interesih. Skupni cilj držav članic je tako vzpostaviti okolje, ki bo omogočalo rast in razvoj gospodarstva, da bo čim bolj konkurenčno na svetovnem trgu. Odprava administrativnih ovir, predvsem pa učinkovit nadzor in pobiranje davkov, so predpogoj za dosego teh ciljev. Pripravljenost na kompromisno sklepanje dogovorov mora biti velika, vendar pa bo konsenz verjetno najteže doseči ravno na področju davkov in davčnih sistemov, zato je trenutno najpomembnejše tesno upravno sodelovanje in pomoč med državami.

Sodelovanje med upravami posameznih držav prinaša nove izkušnje, zglede in morda tudi rešitve, ki jih država pri sebi ni našla. Skozi tovrstne procese bodo namreč države spoznale davčne postopke kot posebne upravne postopke tujih držav. Medsebojno spoznavanje lahko prinese veliko pozitivnih sprememb tudi na nacionalni ravni. Slovenija se namreč do sedaj na področju koordinacije med upravnimi organi še ni posebno izkazala, kljub temu, da ima potrebno pravno podlago že sprejeto. Ustrezna povezava $v$ smislu izmenjave informacij, preglednosti in transparentnosti informacijskih tokov in sodelovanje med organi tako ostaja le črka na papirju. Za opisane korenite spremembe pa je potreben čas.

Aleksandra Heinzer je končala visokošolski strokovni študij in leta 2004 diplomirala na Fakulteti za upravo v Ljubljani. Trenutno je redna študentka četrtega letnika univerzitetnega programa Uprava iste fakultete. Poleg študija opravlja delo davčne svetovalke.

\section{Literatura}

- Bugarič, B. (2004): Evropeizacija državne uprave: vpliv evropskega prava na strukturo nacionalnih državnih uprav. V: Zbornik znanstvenih razprav. Pravna fakulteta, Ljubljana, str. 101-122.

- Grilc, P., Ilešič, T. (2004): Pravo evropske unije. Pravna fakulteta, Ljubljana.

- Heinzer, A. (2004): Novosti davčnega postopka s poudarkom na izvršbi in mednarodnem sodelovanju. Seminarska naloga v okviru predmeta Posebni upravni postopki. Fakulteta za upravo, Ljubljana.

- Jerovšek, T. (2004): Novi davčni postopek. Dnevi slovenske uprave. Fakulteta za upravo, Ljubljana. 


\section{Aleksandra Heinzer \\ Mednarodno sodelovanje \\ v davčnih zadevah v Evropski uniji}

- Klun, M. (2002): Spodbujanje prostovoljnega izpolnjevanja davčnih obveznosti in učinkovitost davčne uprave. V: IX. Dnevi slovenske uprave. Visoka upravna šola, Ljubljana, str.169-84

- Kovač, M. (2004): Obdavčevanje svetovnega dohodka. Davčni inštitut, Maribor.

- Kovač, P. (2004): Vpliv medarodnih načel, standardov in praks na (slovenski) upravni postopek. V: Javna uprava. Inštitut za javno upravo, Ljubljana, str.307-332.

- Kranjec, M. (2003): Davki in proračun, Fakulteta za upravo, Ljubljana.

- $\quad$ Kranjec, M. (2004): Davki in davčna politika v EU, Predavanja 2004/2005.

- Mazi, F. (2004): Obravnavanje kaznivega dejanja davčne zatajitve v primerjavi s prekrškom davčne utaje. Pravosodni bilten, let. 23, št. 3, str. 291-294.

- Schwarze, J. (1992): European administrative law. Office for official Publications of the European Communities, London.

- Vervaele, J.A.E., Klip, A.H.. (2001): European Cooperation between Tax, Customs and Judicial Authorities, g.j. Wiarda Institute, Utrecht University Institute for Legal Studies, BW Utrecht.

\section{Pravni viri}

- Direktiva Komisije 2002/94/ES z dne 9. decembra 2002 o določitvi podrobnih pravil za izvajanje nekaterih določb Direktive Sveta 76/308/EGS o vzajemni pomoči pri poravnavi terjatev v zvezi s prelevmani, davki in drugimi ukrepi, UL L 337, 13. 12. 2002, z vsemi kasnejšimi spremembami in dopolnitvami.

- $\quad$ Direktiva Sveta 76/308/EGS z dne 15. marca 1976 o vzajemni pomoči pri poravnavi terjatev, ki izhajajo iz poslovanja, kot dela sistema financiranja Evropskega kmetijskega usmerjevalnega in jamstvenega sklada in iz prelevmanov in carin, UL L 73, 19. 3. 1976, z vsemi kasnejšimi spremembami in dopolnitvami.

- Pogodba o ustanovitvi Evropske skupnosti (Uradni list C 340 z dne 10. novembra 1997)

- Pogodba o ustavi za Evropo (Uradni list C 310 z dne 16. decembra 2004)

- Zakon o davčnem postopku (UPB Ur.I. RS, št. 25/05). 


\section{Aleksandra Heinzer \\ Mednarodno sodelovanje \\ v davčnih zadevah v Evropski uniji}

\section{SUMMARY \\ International Cooperation Concerning Tax Affairs in European Union}

Reinstatement of homogenous European market forces affiliated countries to harmonize their tax systems. This goal represents a very big challenge for EU, because tax systems within individual states are still quite complicated due to various historical reasons and following of social objectivity goals. Furthermore, taxes are also an instrument of politics. A good tax system is developing on the basis of principles of economic efficiency, objectivity, administrative simplicity and transparency, flexibility and democratic admission of decisions regarding taxes. Tax administration which represents an important role in this development, affects effective tax debiting. Namely, there exists a difference between collected and possible (or potential) taxes. Therefore it is very important how they are actually being collected. In a range of mechanisms for preventing, discovering and abolishing numerous acts on the field of tax evasion mutual administrative cooperation and help among affiliated countries are of extreme importance, because they are following a common goal which is financial interest. In this way cooperation includes mutual help on the administrative or penal field. Which help an affiliated country is going to ask for, depends on the nature of the individual case. Both fields are often strongly interconnected.

In the article the author wishes above all to discuss administrative cooperation in tax matters among affiliated countries. She exposes the influence of European law on Slovene administration, administrative help in EU, defines tax procedure in Republic Slovenia and mutual administrative help among EU affiliated countries concerning tax collection. In the frame of principles of autonomy, primarity and independence of law in EU both primary and secondary legal sources of European law have become binding for Republic Slovenia with the signing of affiliation contract. This represented a difficult requirement also for Slovene administration, because it was necessary to introduce a number of important changes in the law.

In Republic Slovenia international cooperation in tax affairs has been implemented in the frame of tax procedure as a special administrative procedure. Although EU rules command ways of communication cooperation, ways of transmission of data and information between/among 
Aleksandra Heinzer

Mednarodno sodelovanje

v davčnih zadevah v Evropski uniji

competent bodies, a body in relation to a taxpayer acts according to the rules of RS tax procedure, whose framework is impersonated 'LAWS about tax procedure' (Officially selected text, Official document, No 25/05). It was admitted by the National Assembly on 23rd April 2004, but its application started on 1st January 2005, with the exception of provisions concerning insurance of realization and payment of tax obligation, revealing data to the authorized person, tax execution as well as the complete chapter about international cooperation in tax affairs, whose implementation started on 1st May 2004. The main novelty brought by the law is implementation of EU regulations. The law has included some directives which represent an important factor for efficient administrative operation on the field, because tax evasion has been surpassing actual borders between countries for a long time. The institute of international cooperation is located in the fourth part of 'Laws about tax procedure' and includes two fields:

- tax collection

- data exchange.

Administrative help can apply to:

- gaining data important to assess tax obligation of a tax payer in another affiliated country in EU

- handing over documents connected to tax obligation of a tax payer in another affiliated country in EU

- exacting of tax obligation of a tax payer in another affiliated country in EU

- insuring realization of tax obligation of a tax payer in another affiliated country in EU.

The second and the third chapter of the fourth part of 'Laws for tax procedure' define conditions and the way of exchanging data between (among) affiliated countries in EU for individual types of taxations: direct tax, indirect tax, insurance policies.

Help includes three types of exchange:

- exchange based on the demand of a competent agency (it is implemented only on the bases of a request) 


\section{Aleksandra Heinzer \\ Mednarodno sodelovanje v davčnih zadevah v Evropski uniji}

- automatic exchange of data (systematic sending of predefined data on the basis of an agreement saying that the sender doesn't have to judge whatever the data will be useful for the receiver)

- spontaneous exchange of data (non-systematic sending of data which is assumed to be useful for the receiver).

Finaly, the law in the fourth part defines the procedure of a mutual agreement according to the international contract about evading double taxation demanded by a taxpayer or because of an initiative of a competent agency of another country. It also defines rules for bringing forward benefits like reducing, exemption from taxes or refund of tax payment, bringing forward benefits in tax statement and declaration. Cooperation between administrations of individual countries brings new experience, examples and perhaps also solutions which a country has not found by itself.

Through such processes countries will get to know tax procedures as special administrative procedures of foreign countries. Mutual recognition can also bring numerous positive changes on national level. Namely, Slovenia has not been successful on the field of coordination between administrative bodies so far, despite of having already accepted all the basic legislation. Exchanging information, organisation and transparency of information flows and cooperation with other European bodies remain only on paper. Time is essential for the implementation of the described profound changes. 